\title{
Characteristic Evaluation of Various Formulations of Anti-Aging Cream from Carotenoid Extract of Bacterial Symbiont Virgibacillus salarius Strain 19.PP.Sc1.6
}

\author{
Lia Kusmita ${ }^{1,2}$, NFN Mutmainah ${ }^{1}$, Agus Sabdono ${ }^{3}$, Agus Trianto ${ }^{3,4}$, Ocky Karna Radjasa ${ }^{3,5,6}$ \\ and Ratih Pangestuti $7, *$ (D)
}

Citation: Kusmita, L.;

Mutmainah, N.; Sabdono, A.;

Trianto, A.; Radjasa, O.K.;

Pangestuti, R. Characteristic

Evaluation of Various Formulations

of Anti-Aging Cream from

Carotenoid Extract of Bacterial

Symbiont Virgibacillus salarius Strain

19.PP.Sc1.6. Cosmetics 2021, 8, 120 .

https://doi.org/10.3390/

cosmetics 8040120

Academic Editor: Piera Di Martino

Received: 16 November 2021

Accepted: 10 December 2021

Published: 17 December 2021

Publisher's Note: MDPI stays neutral with regard to jurisdictional claims in published maps and institutional affiliations.

Copyright: (c) 2021 by the authors. Licensee MDPI, Basel, Switzerland. This article is an open access article distributed under the terms and conditions of the Creative Commons Attribution (CC BY) license (https:// creativecommons.org/licenses/by/ $4.0 /)$.
1 STIFAR "Yayasan Pharmasi", Letjend Sarwo Edie Wibowo KM 1, Semarang 50124, Central Java, Indonesia; liakusmita@stifar.ac.id (L.K.); mutmainah@stifar.ac.id (N.M.)

2 Coastal Resources Management, Faculty of Fisheries and Marine Sciences, Universitas Diponegoro. St. Prof. H. Soedarto, S.H., Tembalang, Semarang 50275, Indonesia

3 Department of Marine Science, Faculty of Fisheries and Marine Science, Tembalang, Diponegoro University, St. Prof. Soedarto SH., Semarang 50275, Indonesia; agussabdono@lecturer.undip.ac.id (A.S.); agustrianto@lecturer.undip.ac.id (A.T.); Ocky001@brin.go.id (O.K.R.)

4 Marine Natural Products Laboratory, Building of Central Laboratory Lv. 2, Tembalang Campus, Diponegoro University, St. Prof. Soedarto SH., Semarang 50275, Indonesia

5 Tropical Marine Biotechnology Laboratory, Building of Marine and Oceanography Laboratory Lv. 2, Faculty of Fisheries and Marine Science, Tembalang Campus, Diponegoro University, St. Prof. Soedarto SH., Semarang 50275, Indonesia

6 Research Center for Oceanography, National Research and Innovation Agency (BRIN), Jakarta 14430, Indonesia

7 Research and Development Divisions for Marine Bio Industry (BBIL), National Research and Innovation Agency (BRIN), Pamenang 83352, Indonesia

* Correspondence: ratih.pangestuti@lipi.go.id

Abstract: Premature aging can be triggered by free radicals from UV rays, since exposure to these rays can cause the skin to experience oxidative stress. Oxidative stress induces intracellular DNA damage, protein denaturation, and lipid peroxidation that lead to cell death. However, cell death can be prevented with antioxidants such as carotenoids, which are among the potential natural compounds for its treatment. Sources of carotenoids include microbial symbionts associated with Sinularia sp., one of which is the bacterium Virgibacillus salarius strain 19.PP.Sc1.6, a carotenoidproducing bacteria. This study aims to explore the utilization of carotenoids from the bacterium $V$. salarius strain 19.PP.Sc1.6 for the preparation of anti-aging creams. Furthermore, the method employed three formulations (vs, ow, and wo) containing different types of cream tested for stability, and antioxidant and sunscreen abilities. The results obtained established that the carotenoid extract from $V$. salarius strain 19.PP.Sc1.6 was more stable in the cream vs. the oil-in-water type cream with an anionic emulsifier.

Keywords: cream; carotenoids; antioxidants; sunscreen; bacterial symbiont

\section{Introduction}

Premature aging is a degenerative disease characterized by dry, wrinkled, rough skin and black spots [1]. Two factors trigger premature aging, namely internal factors such as stress, endurance, hormonal changes, and health as well as external factors including ultraviolet rays and free radicals. Free radicals are oxygen-containing molecules whose atomic arrangement is unstable and, hence, undergo chain reactions that can occur in the body and lead to continuous damage [2].

Free radicals are very reactive and dangerous substances that cause damage to the tissues of the body which may lead to the development of various diseases in old age [3]. However, free radicals are possible to overcome by using antioxidants [4] which stop 
chain reactions triggered by free radicals by donating electrons to the unstable molecules. Examples of antioxidant compounds include carotenoids, vitamin C, and vitamin E [5].

Carotenoids are compounds proven to be potential antioxidants [6-10] as they contain a long-chain isoprene compound with a conjugated double bond $[5,7,11]$. The conjugated double bond removes singlet oxygen and deactivates other free radicals occurring through the electron transfer process $[12,13]$. Subsequently, compounds that have conjugated double bonds can be found in terrestrial and marine organisms. Compounds from marine organisms have unique characteristics and several discoveries about new bioactive compounds for antibiotics, anti-cancer, pharmaceuticals, cosmetics, enzymes, and pigments have been obtained from many coral ecosystems, especially soft corals.

Massive utilization of soft corals should not be used, since it will cause damage to the ecosystem. The bacterial symbiont associated with soft coral could become a potential alternative which produces carotenoids as a source of antioxidants [14,15]. Cosmetic formulations that can be applied effortlessly and comfortably are required when using carotenoid compounds. Hence, the cosmetic formulation that is preferred is in the form of cream. Cream is the selected semi-solid preparation easily spread evenly on the skin, is non-sticky, and is easy to clean so it is comfortable to use by consumers. The use of symbiont bacteria as a source of cosmetic raw materials is the latest breakthrough that needs to be developed.

\section{Materials and Methods}

\subsection{Materials and Tools}

The bacterial symbiont $V$. salarius strain 19.PP.Sc1.6 isolated from Sinularia sp. originated from Panjang Island, Jepara, Central Java, Indonesia; the specific point is at the coordinates of " $6^{\circ} 34^{\prime} 37.35^{\prime \prime} \mathrm{S}^{\prime}$, " $110^{\circ} 37^{\prime} 52.01^{\prime \prime} \mathrm{E}^{\prime}$. Materials required include methanol (analytical grade) purchased from Merck (Darmstadt, Germany); 2,2-Diphenyl-1-picrylhydrazyl (DPPH) from Sigma-Aldrich Co. (St. Louis, MO, USA). Other ingredients used in the cream formulations such as stearic acid, glycerin, Na tetraborate, triethanolamine (TEA), lanolin, sunflower oil, beeswax, cetyl alcohol, span 80, glycerol monostearate, and Tween 80 were purchased from Merck (Darmstadt, Germany). The instruments used were an UV-vis Shimadzu 1240 spectrophotometer (Kyoto, Japan), Brookfield LVDV-I Prime Viscometer (Toronto, ON, Canada), pH meter digital USB Phs 3c 3d Rohs, centrifuge IEC Centra MP4R (Thermo Electron, Waltham, MA, USA), and orbital shaker Daihan SHO 2D (Wonju, Korea).

\subsection{Isolation of Bacterial Symbiont of Sinularia sp.}

The Silunaria sp. tissues were placed into sterile petri dishes that were partially filled with sterilized sea water. The surfaces of the soft coral tissues were cut away, and only the inside of the sample was used for microbial isolation. For bacterial isolation, a series of dilutions was conducted for all samples. From each petri dish, $10 \mathrm{~mL}$ of the sample was collected with a sterile pipette and placed into a flask containing $90 \mathrm{~mL}$ of sterilized sea water to obtain a $10^{-1}$ dilution. From the $10^{-1}$ dilution, $1 \mathrm{~mL}$ was moved into a tube containing $9 \mathrm{~mL}$ of sterile sea water to obtain a $10^{-2}$ dilution. This dilution process was repeated until a $10^{-5}$ dilution was obtained. A sample $(1 \mathrm{~mL})$ of each dilution series was collected and placed into a sterile petri dish containing Zobell 2216E agar medium (Himedia, Mumbai, India) for bacterial isolation. Then, the petri dishes were incubated at $30^{\circ} \mathrm{C}$ for 2 days. Yellow-colored bacterial colonies that grow on the surface of the agar media were separated by a streak method to obtain pure bacterial strains.

\subsection{Bacterial Symbiont Culture}

The bacteria $V$. salarius strain 19.PP.Sc1.6 [16] was inoculated by transferring $1 \mathrm{~mL}$ of the isolate into $2 \mathrm{~L}$ of sterile Zobell Marine Broth 2216 (Himedia, Mumbai, India). It was then placed on the shaker at $100 \mathrm{rpm}$ at $27^{\circ} \mathrm{C}$ until the media color turned yellow ( \pm 7 days). Subsequently, the symbiotic bacteria that had produced carotenoids were isolated and 
centrifuged for $15 \mathrm{~min}$ at $6000 \mathrm{rpm}$, after which the pellets separated and then filtered using Whatman filter paper No 1 (Maidstone, UK).

\subsection{Carotenoid Extraction}

Extraction of carotenoids using the fast of maceration method carried out in a dark room. Methanol (analytical grade) purchased from Merck (Darmstadt, Germany) was added to the pellet culture and then centrifuged for $10 \mathrm{~min}$ at $6000 \mathrm{rpm}$. Subsequently, a filtrate containing carotenoids and pellets in the form of a bacterial mass was obtained, filtered with a Wahtman No 1 filter paper, evaporated, and dried using N gas [14,15].

\subsection{Cream Formulations}

The formula employed three formulations with different types of cream, namely vs, ow, and wo [16-18]. The formula used is as shown in the Table 1.

Table 1. Cream formulas of carotenoid extract V. salarius strain 19.PP.Sc1.6.

\begin{tabular}{cccccc}
\hline \multicolumn{2}{c}{ Formula 1: Cream vs } & \multicolumn{2}{c}{ Formula 2: Cream ow } & \multicolumn{2}{c}{ Formula 3: Cream wo } \\
\hline Stearate Acid & $14 \%$ & Sunflower oil & $6.5 \%$ & Lanolin & $10.2 \%$ \\
\hline Glicerin & $10 \%$ & $\begin{array}{c}\text { Glycerol } \\
\text { monostearate }\end{array}$ & $2 \%$ & Sunflower oil & $40 \%$ \\
\hline Na tetraborate & $0.25 \%$ & Cetyl alcohol & $3 \%$ & Beeswax & $5 \%$ \\
\hline TEA & $1 \%$ & Tween 80 & $6 \%$ & Cetyl alcohol & $5 \%$ \\
\hline Carotenoid extract & $0.44 \%$ & Carotenoid extract & $0.44 \%$ & Span 80 & $3 \%$ \\
\hline Aqua ad & $100 \%$ & Aqua ad & $100 \%$ & Carotenoid extract & 0.44 \\
\hline & & & Aqua ad & $100 \%$ \\
\hline
\end{tabular}
strain 19.PP.Sc1.6.

\subsubsection{Formula 1: Cream vs}

We melted the stearic acid and glycerin in a bowl. Na tetraborate and TEA were dissolved in a little water, then put in a solution of steric acid and glycerin. Then, we stirred and homogenized, and added a little water so that the results are good. The final step was to add the carotenoid extract and stir until evenly distributed.

\subsubsection{Formula 2: Cream ow}

First, the glycerol monostearate and cetyl alcohol were melted in cup 1. Sunflower and Tween 80 were mixed in cup 2. After that, we placed the mixture in cup 2 into cup 1 . This was stirred until homogeneous with a little hot water. Finally, we added the carotenoid extract and stirred until homogeneous.

\subsubsection{Formula 3: Cream wo}

The first step was to melt the lanolin, sunflower, and span 80 in a cup 1. Then, we melted the beeswax and cetyl alcohol in a cup 2 . We mixed cup 2 into cup 1 while stirring and homogenized it with a little hot water. Finally, we added carotenoid extract and homogeneous.

\subsection{Cream Evaluation}

The characteristics of three cream formulations were evaluated; the initial evaluation carried out was an organoleptic test. In organoleptic tests, observations include changes in color, odor (rancidity), and feel. In the organoleptic test, 25 people were used as respondents, consisting of 15 trained and 10 untrained people. The following test was homogeneity, which is accomplished by applying the cream to glass plates and observing the evenness of the color, whether it is even or not. Subsequently, in the $\mathrm{pH}$ test, the cream was deposited into a glass beaker, and then the $\mathrm{pH}$ measurement was done using a $\mathrm{pH}$ meter that had previously been calibrated with a Dappar standard ( $\mathrm{pH}$ of 4 and $\mathrm{pH}$ 7). The scatter power 
test was carried out on transparent glass placed on graph paper and $0.5 \mathrm{~g}$ of cream was placed on the glass and then covered with another transparent glass and left for $\pm 5 \mathrm{~s}$ to obtain the diameter of the area formed. Then, different weights of 50, 100, 150, 200, 250, 300, 350,400 , and $450 \mathrm{~g}$ were placed on the transparent glass and the diameter of the area formed was observed. The specifications state that the cream should spread easily and evenly. Meanwhile, the cream viscosity test was determined using a Brookfield LVDV-I Prime Viscometer. An adhesion test was carried out with a glass object marked as $4 \times 2.5 \mathrm{~cm}$, then as much as $0.25 \mathrm{~g}$ of cream was placed at the midpoint of the area and covered with other glass objects. Therefore, a load of $1 \mathrm{~kg}$ was placed for $5 \mathrm{~min}$, then the two glass objects that had been attached were mounted on the test equipment which was given a load of 80 g. After this, the time needed to separate the two glass objects was noted. Observations for all tests were carried out weekly for 5 weeks.

\subsection{Measurement of Antioxidant Activity}

Creams dissolved in methanol were prepared into a series of concentrations. Hence, a total of $3 \mathrm{~mL}$ of the sample was diluted with $1 \mathrm{~mL}$ of $0.1 \mathrm{mM}$ DPPH solution and allowed to stand for $30 \mathrm{~min}$. On settling, the solution was homogenized and its absorption was measured using a spectrophotometer at a wavelength of $517 \mathrm{~nm}$. The absorbance of the control solution, that is, DPPH without test solution, was also read. Furthermore, the amount of antioxidant activity was measured using the following equation [19]:

$$
\% \text { Inhibitory }=\frac{[A 517]_{\text {control }}-[A 517]_{\text {sample }}}{[A 517]_{\text {control }}} \times 100 \%
$$

where control $=$ stock solution of DPPH.

\subsection{Measurement of Sun Protection Factor (SPF)}

Measurement of the Sun Protection Factor (SPF) value was done in vitro. The SPF test was performed to determine the sunscreen activity of the cream using a UV-Vis spectrophotometer. Each cream, weighing $0.1 \mathrm{~g}$, was dissolved in $100 \mathrm{~mL}$ of methanol in a volumetric flask and filtered using Whatman No. 1. A total of $3 \mathrm{~mL}$ of the solution was put into a cuvette to measure its absorbance using a UV-Vis spectrophotometer. Subsequently, determination of the SPF value using the UV-Vis spectrophotometer was known from the characteristics of cream uptake at wavelengths of 290 to $320 \mathrm{~nm}$ with intervals of $5 \mathrm{~nm}$. Calculation of SPF value uses the following equation [20,21]:

$$
\mathrm{SPF}=\mathrm{CV} \times \sum_{290}^{320} E E(\lambda) \times I(\lambda) \times \operatorname{abs}(\lambda)
$$

where:

$\mathrm{CV}=$ correction factor;

$E E=$ Spectrum of erythema effect;

$I=$ spectrum of sun's intensity;

abs $=$ Absorbance of sample.

\section{Results}

\subsection{Bacteria Culture and Carotenoid Extract}

V. salarius strain 19.PP.Sc1.6 is a sample of bacterial symbiont associated with a soft coral Sinularia sp. [16]. Bacteria culture and carotenoid extract of V. salarius strain 19.PP.Sc1.6 are shown in Figure 1. 


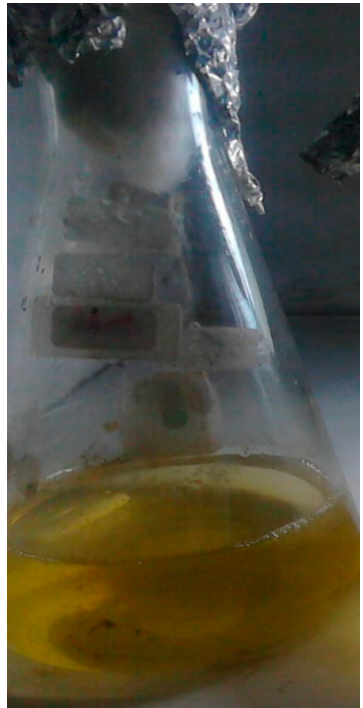

(a)

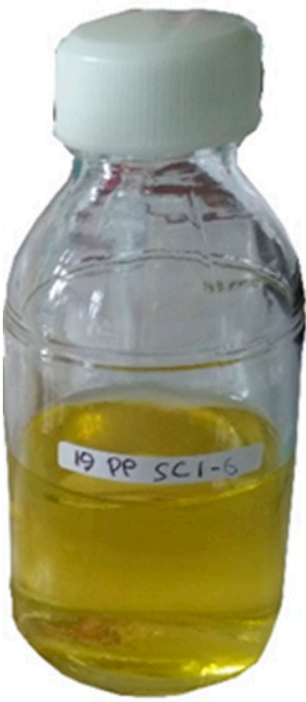

(b)

Figure 1. (a) Bacterial culture and (b) carotenoid extract of $V$. salarius strain 19 PPSc1.6.

\subsection{Cream Evaluation}

Photoaging creams were prepared using three formulations with different types of creams (Figure 2). The first formulation was cream vs, a type of oil-in-water cream with an anionic emulsifier, the second is cream ow, a type of oil-in-water cream with a nonionic emulsifier [22], and the third is cream wo, a water-in-oil cream. The results of the evaluated cream preparations are shown in Table 2 . The stability test of this study was carried out at room temperature; the results are shown in Table 3 and Figure 3.

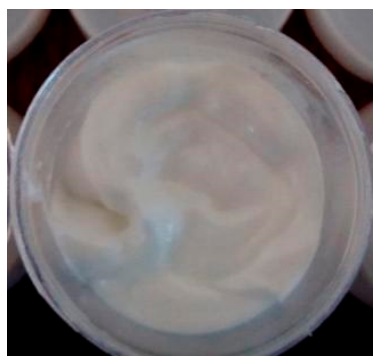

(a)

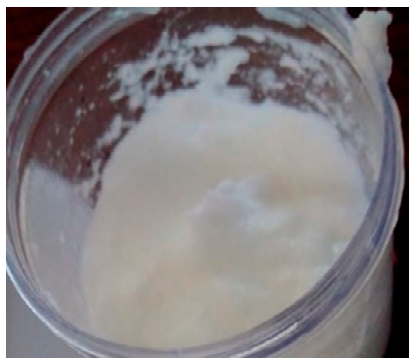

(b)

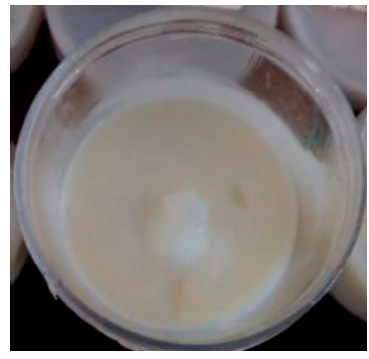

(c)

Figure 2. vs (a), ow (b), and wo (c) cream.

Table 2. Evaluation of different parameters of cream formulations.

\begin{tabular}{cccc}
\hline Cream Evaluation & Formula 1. Cream vs & Formula 2 Cream ow & Formula 3. Cream wo \\
\hline Color & White & White & Yellowish \\
\hline Smell & Odorless & Odorless & Odorless \\
\hline Feel & Soft & Soft & Soft \\
\hline Homogeneity & Homogeneous & Homogeneous & Homogeneous \\
\hline pH & 6.5 & 5.7 & 5.2 \\
\hline Spreadability $(\mathrm{cm})$ & 7.8 & 10.2 & 7 \\
\hline Viscosity $(\mathrm{cps})$ & 11,301 & 5642 & 11,506 \\
\hline Stickiness $(\mathrm{sec})$ & 0.71 & 0.80 & 0.80 \\
\hline
\end{tabular}


Table 3. Organoleptic stability of cream formulation.

\begin{tabular}{|c|c|c|c|c|}
\hline Cream Evaluation & Week & Formula 1. Cream vs & Formula 2 Cream ow & Formula 3. Cream wo \\
\hline \multirow[t]{5}{*}{ Color } & 1 & White & White & Yellowish \\
\hline & 2 & White & White & Yellowish \\
\hline & 3 & White & White & Yellowish \\
\hline & 4 & White & Yellowish white & Yellowish \\
\hline & 5 & White & Yellowish white & Yellowish \\
\hline \multirow[t]{5}{*}{ Smell } & 1 & Odorless & Odorless & Odorless \\
\hline & 2 & Odorless & Odorless & Odorless \\
\hline & 3 & Odorless & Odorless & Odorless \\
\hline & 4 & Odorless & Odorless & Odorless \\
\hline & 5 & Odorless & Odorless & Odorless \\
\hline \multirow[t]{5}{*}{ Feel } & 1 & Soft & Soft & Soft \\
\hline & 2 & Soft & Soft & Soft \\
\hline & 3 & Soft & Soft & Soft \\
\hline & 4 & Soft & Soft & Soft \\
\hline & 5 & Soft & Soft & Soft \\
\hline \multirow[t]{5}{*}{ Homogeneity } & 1 & Homogeneous & Homogeneous & homogeneous \\
\hline & 2 & Homogeneous & Homogeneous & homogeneous \\
\hline & 3 & Homogeneous & Homogeneous & Homogeneous \\
\hline & 4 & Homogeneous & Homogeneous & 2 phases \\
\hline & 5 & Homogeneous & 2 phases & 2 phases \\
\hline
\end{tabular}

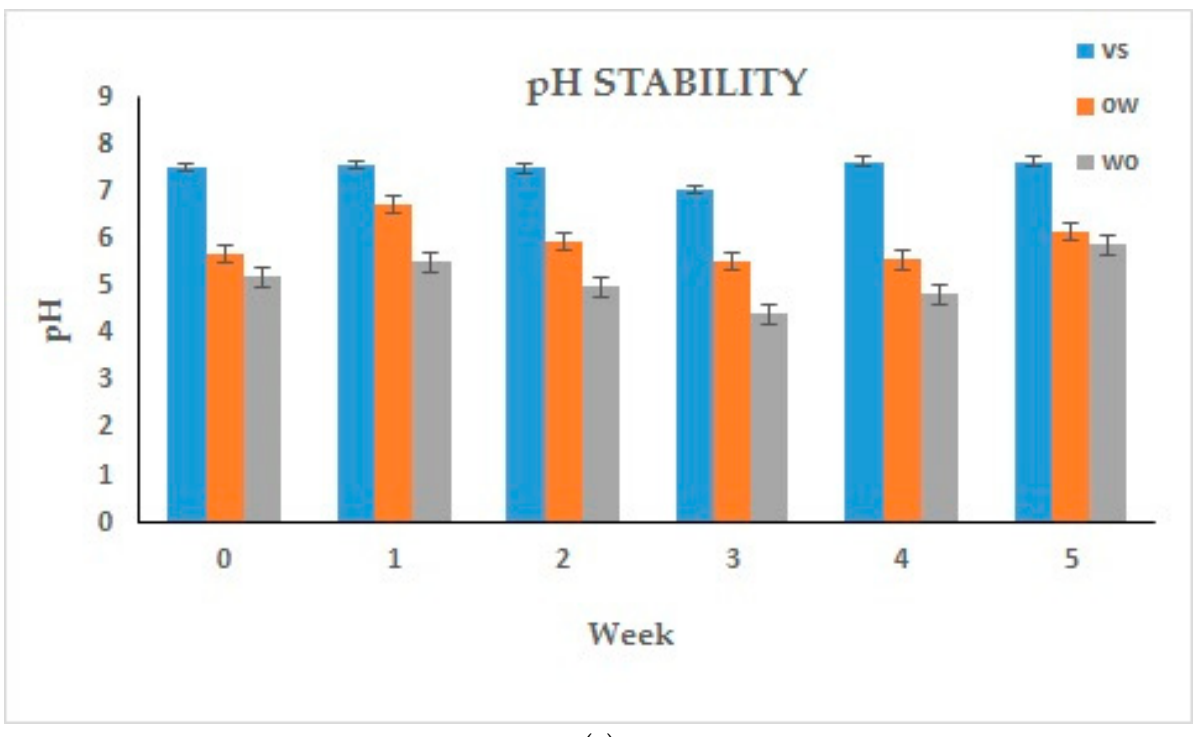

(a) 


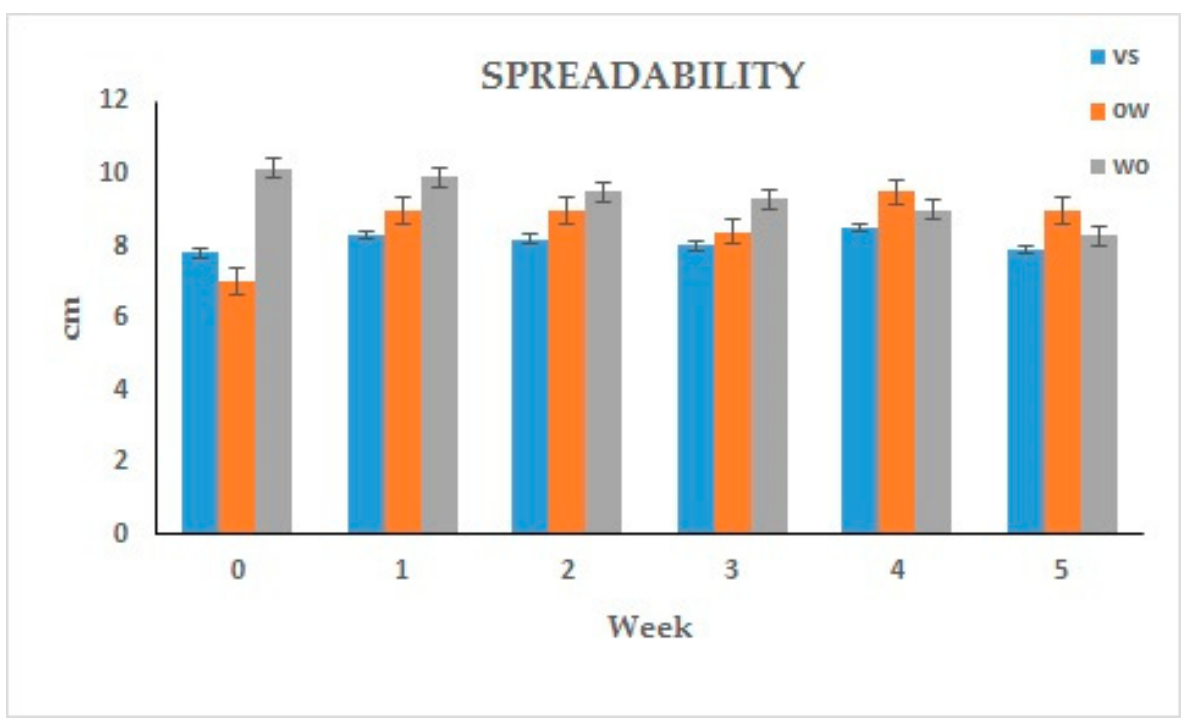

(b)

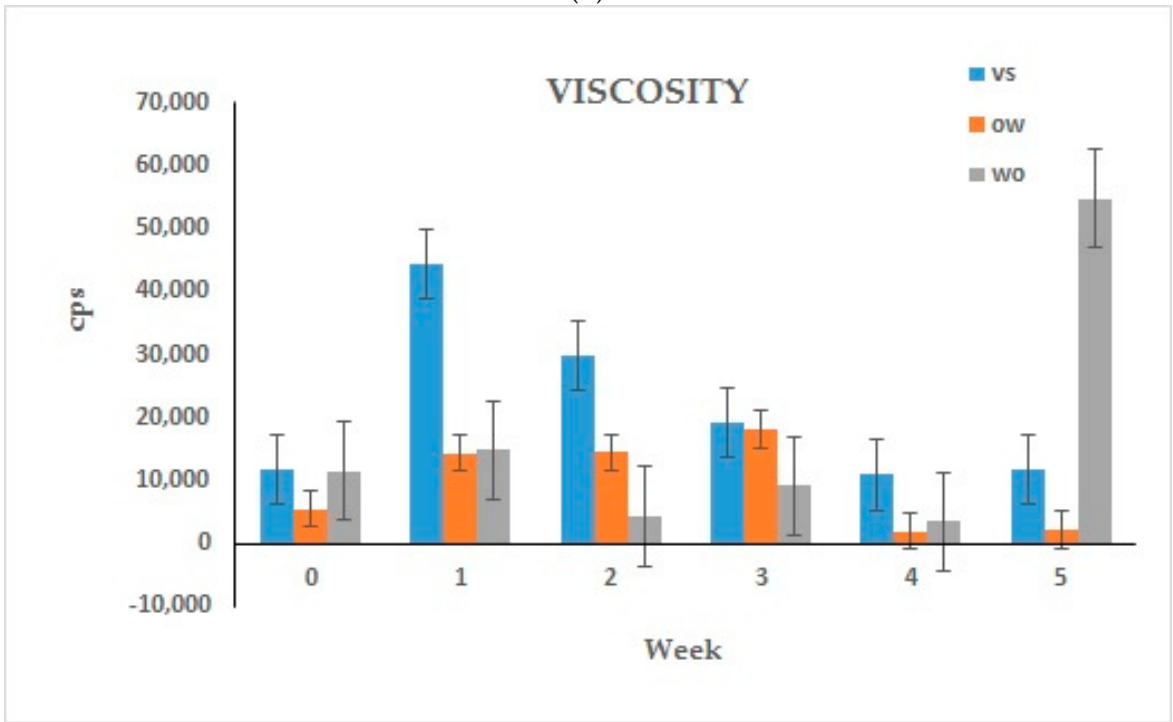

(c)

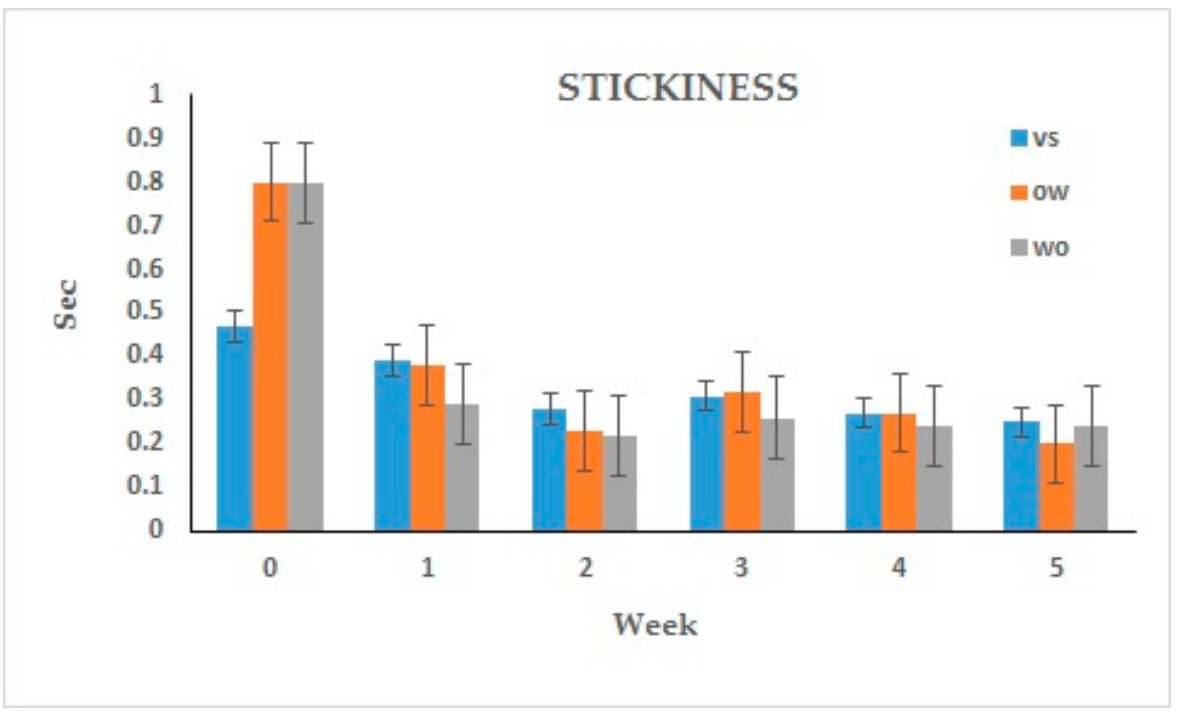

(d)

Figure 3. Evaluation of cream stability (a) $\mathrm{pH}$; (b) spreadability; (c) viscosity; (d) stickiness. 


\subsection{Antioxidant Activity}

The test for antioxidant activity was done before and after storage for five weeks. The results of the antioxidant activity are shown in Figure 4.

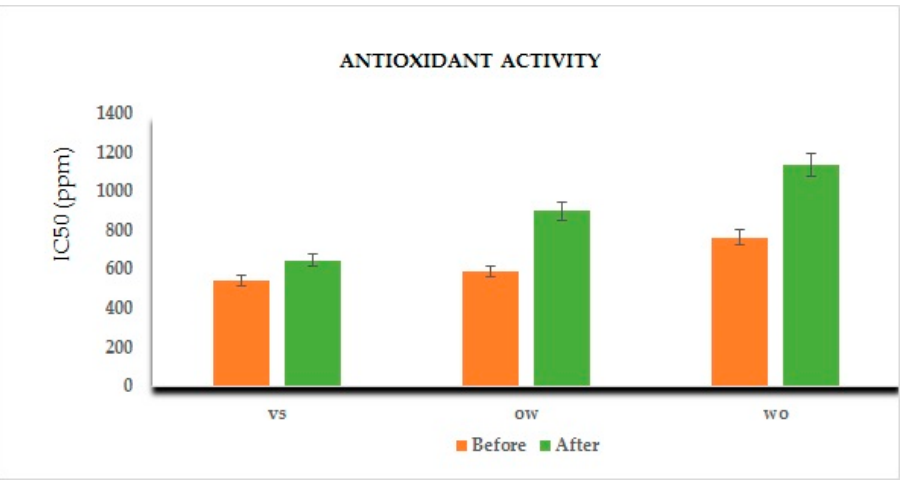

(a)

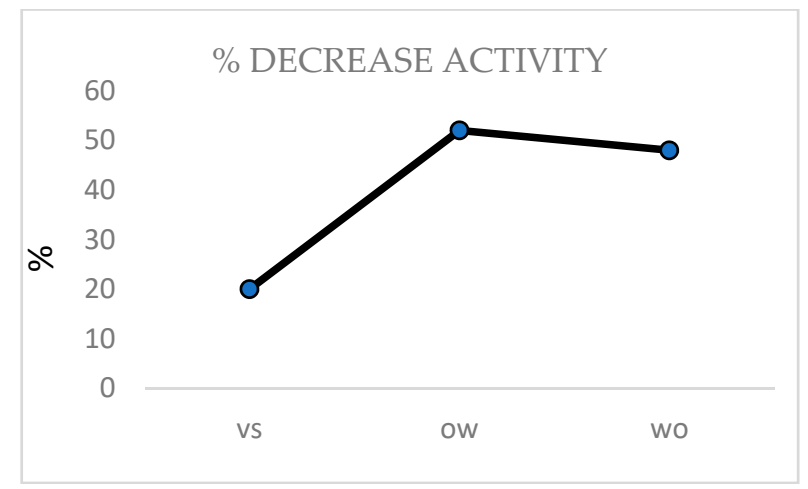

(b)

Figure 4. Antioxidant activity of the cream before and after (a) storage and \% decrease activity (b).

\subsection{Measuring of Sun Protector Factor (SPF)}

The sunscreen activity in the cream was measured by observing the SPF value. Therefore, the SPF measurement results before and after storage are shown in Figure 5.

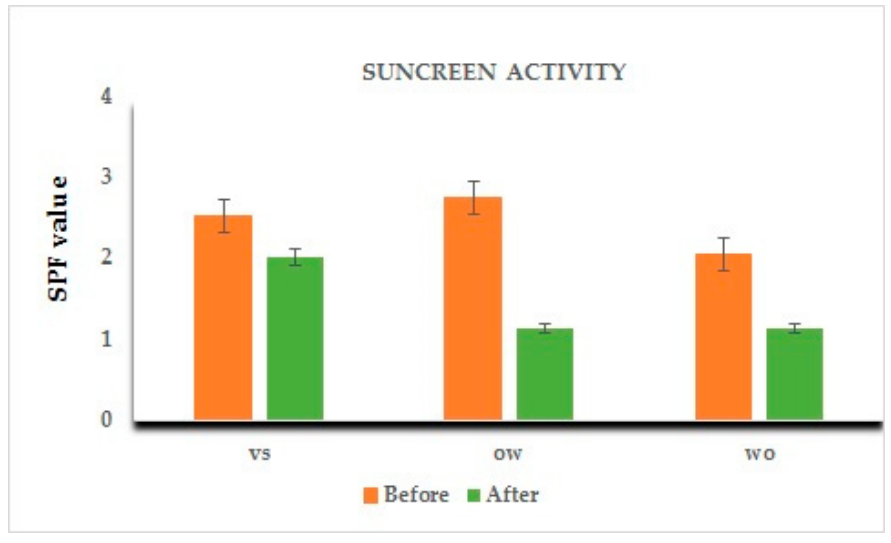

(a)

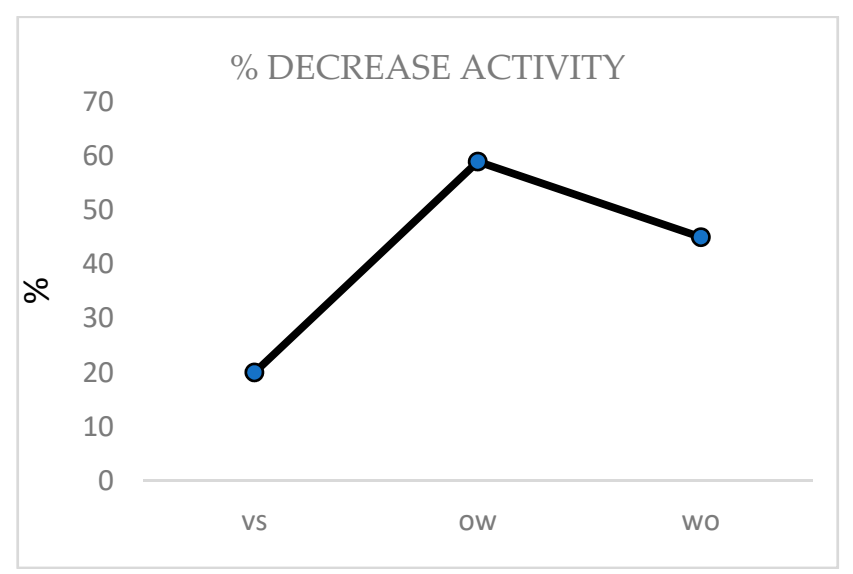

(b)

Figure 5. Sunscreen activity of the cream before and after storage (a) and \% decrease activity (b).

\section{Discussion}

\subsection{Cream Evaluation}

On evaluation, the creams possessed the appropriate specifications for cream preparations as observed in the organoleptic test. Similarly, the results of the $\mathrm{pH}$ measurement also met the specifications for skin $\mathrm{pH}$, as cream preparations must have a $\mathrm{pH}$ that matches the $\mathrm{pH}$ of the skin in the range of 4.5-6.5 [23-25]. Spread also affects the nature of the cream when used as a topical preparation because the greater the spread area, the greater the surface area of the skin that comes into contact with the cream, and this ensures easy distribution of active substances [1]. The viscosity test results of the three creams according to the specifications for semi-solid preparations are $4000-40,000 \mathrm{cps}$ [26]. Furthermore, stickiness is related to the duration of time the cream stays in contact with the skin, and the longer the cream sticks to the skin, the more effective the active substance will be [4]. The results of the three creams showed almost similar stickiness.

The stability results for the third organoleptic test indicated that the cream was stable because there were no changes in color, odor, or texture. Furthermore, the homogeneity test is essential because it is related to the effectiveness of the cream at the same level 
of use. Hence, the active substance will be the same with every use if the preparation is homogenous [27]. Cream is considered to be homogeneous when there are no clumps seen physically in it [28]. For ow and wo creams, a two-phase separation occurred at weeks four and five, and this separation occurred due to the possibility of instability of the active substance and a decrease in the emulsifier [29].

For the third $\mathrm{pH}$ test, the cream was also stable in the skin $\mathrm{pH}$ range, and therefore it is safe to use. Creams with extremely alkaline $\mathrm{pH}$ cause scaly skin while an extremely acidic $\mathrm{pH}$ will cause skin irritation $[30,31]$. Therefore, monitoring the $\mathrm{pH}$ of the preparation is very important to ensure the stability of the emulsion as significant $\mathrm{pH}$ changes indicate a chemical reaction that can give an idea of product instability [32]. The spread of the three formulations increased during storage due to a decrease in the viscosity of the cream. Decreases in fluid resistance to flow increase the spread of cream [4]. The viscosity of the three creams had a similar tendency to decrease, as a decrease in viscosity can occur due to a decrease in emulsion stability over time. The viscosity test is also strongly influenced by viscosity as the greater the viscosity, the longer the adhesion. In addition, if the viscosity decreases, the sticking power will follow as well [23].

ANOVA analysis showed that the level of significance was $>0.05$ for the $\mathrm{pH}$, viscosity, and stickiness, which indicates that storage time has no significant effect on $\mathrm{pH}$, viscosity, or stickiness. The statistical results indicate that the resulting cream formula is quite stable in storage for five weeks. Furthermore, the ANOVA analysis on spreadability showed that there was no significant difference between the weekly variants; however, there was a significant difference in the cream variant, hence, the variation between the vs and wo formulas was significantly different.

\subsection{Antioxidant Activity}

The oil-in-water cream had better antioxidant activity compared to the water-in-oil type. These results are similar to the results obtained by previous research [17] that stated that carotenoids are more stable in the oil-in-water cream type. Furthermore, of the two types of oil-in-water, namely vs and ow, vs had better antioxidant activity, as creams with an anionic emulsifier had better antioxidant activity than those with nonionic emulsifiers [22]. The reducing effect of the active ingredient on DPPH may also be influenced by stearic acid used as an emulsifier in cream vs. Stearic acid can also help carotenoids in reducing DPPH.

In this study, cream storage was also carried out for five weeks to compare antioxidant activity before and after storage. The results obtained indicated that antioxidant activity decreased during storage. In addition, carotenoids used as active ingredients in cream preparations had a decreased number [17], which caused a reduction in antioxidant activity. Statistical data with ANOVA showed a level of significance of $>0.05$, which indicates that storage time has no significant effect on the value of the antioxidant activity.

\subsection{Measuring of Sun Protector Factor (SPF)}

By definition, cream is categorized as having minimum sun protection if it has an SPF value of 2-4 [32]. The three creams before storage had sunscreen protection; however, after five weeks of storage, the sunscreen protection ability was lost because the SPF value was below 2 . The decrease in the SPF value might be influenced by a decrease in carotenoid levels when it is the active ingredient since carotenoids are susceptible to oxidation during storage [33]. Furthermore, when degradation occurs, the biological activity will be reduced $[13,34]$. Statistical results show a significance value of $0.109>0.05$, which means that the storage time does not result in a significant difference in the SPF value.

\section{Conclusions}

V. salarius strain 19.PP.Sc1.6 is a bacterium associated with Sinularia sp. that produces carotenoids with antioxidant and anti-aging properties. This research utilized carotenoids from V. salarius strain 19.PP.Sc1.6 for cream preparation and the results showed that these carotenoids were stable in the oil-in-water type with an anionic emulsifier (formulation vs). Furthermore, 
the antioxidant activity and sunscreen protection were the highest in formulation vs, indicating that the stability of carotenoids affects the antioxidant and sunscreen activity.

Utilization of symbiotic microorganisms, especially bacteria, needs to be developed for cosmetic raw materials. The advantage that can be obtained is that the growth of bacteria is fast and does not over-exploit the ecosystem, therefore it does not damage the environment.

Author Contributions: O.K.R., A.S. and A.T.: Conceptualization; L.K. and N.M.: methodology, sample preparation, investigation, and analysis; L.K.: writing-original draft preparation; R.P.: writing-review and editing. All authors have read and agreed to the published version of the manuscript.

Funding: This research was partly funded by the Ministry of Research, Technology, and Higher Education, Indonesia under the Program Beasiswa Pendidikan Pascasarjana Dalam Negeri (BPPDN) decree number 2903.9/D3/PG/2017 and Hibah Disertasi Doctor.

Data Availability Statement: The data presented in this study are available on request from the corresponding author.

Acknowledgments: We would like to express our gratitude to Wahyu Wulandari for her contribution to the project.

Conflicts of Interest: The authors declare no conflict of interest.

\section{References}

1. Ratnasari, D.; dan Puspitasari, R.N. Optimization of anti-aging cream preparation formula from purple eggplant extract (Solanum melongena L.) dan Tomat (Solanum lycopersicum L.). J. Ris. Kesehat. 2018, 7, 66-71. [CrossRef]

2. Wahdaningsih, S.; Setyowati, E.P.; Wahyuono, S. Free radical scavenging activity of (Alsophila glauca J. Sm). Tradit. Med. J. 2011, 16, 156-160.

3. Mathew, B.B.; Tiwari, A.; Jatawa, S.K. Free radicals and antioxidants: A Review. J. Pharm. Res. 2011, 4, 4340-4343.

4. Swastika, A.; dan Purwanto, M. Antioxidant activity of cream dosage form of tomato extract (Solanum lycopersicum L.). Tradit. Med. J. 2013, 18, 132-140.

5. Stahl, W.; Sies, H. Antioxidant activity of carotenoids. Mol. Asp. Med. 2003, 24, 345-351. [CrossRef]

6. Fernández-García, E.; Carvajal-Lérida, I.; Jarén-Galán, M.; Garrido-Fernández, J.; Pérez-Gálvez, A.; Hornero-Méndez, D. Carotenoids bioavailability from foods: From plant pigments to efficient biological activities. Food Res. Int. 2012, 46, 438-450. [CrossRef]

7. Fiedor, J.; Burda, K. Potential Role of Carotenoids as Antioxidants in Human Health and Disease. Nutrients 2014, 6, 466-488. [CrossRef]

8. Avalos, J.; Limón, M.C. Biological roles of fungal carotenoids. Curr. Genet. 2015, 61, 309-324. [CrossRef]

9. Woodside, J.V.; McGrath, A.J.; Lyner, N.; McKinley, M.C. Carotenoids and health in older people. Maturitas 2015, 80, 63-68. [CrossRef]

10. Ndayishimiye, J.; Chun, B.S. Optimization of carotenoids and antioxidant activity of oils obtained from a co-extraction of citrus (Yuzu ichandrin) by-products using supercritical carbon dioxide. Biomass Bioenergy 2017, 106, 1-7. [CrossRef]

11. Gross, J. Pigmen in Vegetables; Van Nastrand Reinhold: New York, NY, USA, 1991; pp. 3-51.

12. Dutra, E.A.; da Dag Oliveira, C.; Kedor-Hackmann, E.R.M.; Santoro, M.I.R.M. Determination of sun protection factor (SPF) of sunscreens by ultraviolet spectrophotometry. Rev. Bras. Ciên. Farm. 2004, 40, 381-385. [CrossRef]

13. Rao, A.V.; Rao, L.G. Carotenoids and human health. Pharmacol. Res. 2007, 55, 207-216. [CrossRef]

14. Kusmita, L.; Mutiara, E.V.; Nuryadi, H.; Pratama, P.A.; Wiguna, A.S.; Radjasa, O.K. Characterization of carotenoid pigments from bacterial symbionts of soft-coral Sarcophyton sp. from North Java Sea. Int. Aquat. Res. 2017, 9, 61-69. [CrossRef]

15. Nugraheni, S.A.; Khoeri, M.M.; Kusmita, L.; Widyastuti, Y.; Radjasa, O.K. Characterization of carotenoid pigments from bacterial symbionts of seagrass Thalassia hemprichii. J. Coast. Dev. 2010, 14, 51-60.

16. Kusmita, L.; Nuryadi, H.; Widyananto, P.A.; Muchlissin, S.; Sabdono, A.; Radjasa, O.K. Bioactivity of carotenoid produced by soft coral symbiotic microorganisms from Panjang and Karimunjawa Island, central Java, Indonesia. Biodiversitas 2021, 22, 732-740. [CrossRef]

17. Igieska-Kalwat, J. Studies on stability of emulsions containing carotenoids. Acta Biochim. Pol. 2018, 65, 455-463.

18. Igieska-Kalwat, J. Analysis of Composition and Stability of Emulsions Containing Carotenoids with High-Performance Liquid Chromatography (HPLC). Biomed. J. Sci. Tech. Res. 2019, 13, 9764-9773.

19. Kawarkhe, P.R.; Deshmane, S.V.; Biyani, K.R. Formulation and Evaluation of Antioxidant Face Cream Containing Raspberry Fruit and Grape Seeds Extract. Res. J. Top. Cosmet. Sci. 2016, 7, 73-78. [CrossRef]

20. Mbanga, L.; Mulenga, M.; Mpiana, P.T.; Bokolo, K.; Mumbwa, M.; Mvingu, K. Determination of Sun Protection Factor (SPF) of Some Body Creams and Lotions Marketed in Kinshasa by Ultraviolet Spectrophotometry. Int. J. Adv. Res. Chem. Sci. 2014, 1, 7-13. 
21. Abdassah, M.; Aryani, R.; dan Surachman, E.; Muchtaridi, M. In-vitro assessment of effectiveness and photostability avobenzone in cream formulations by combination ethyl ascorbic acid and alpha tocopherol acetate. J. Appl. Pharm. Sci. 2015, 5, 70-74. [CrossRef]

22. Hamzah, N.; Ismail, I.; Sandi, A.D.A. Effect of emulsifier on antioxidant activity of rosella flower ethanol extract cream (Hibiscus Sabdariffa linn). J. Kesehatan. 2014, 7, 376-385.

23. Wasitaatmadja, S.M. Penuntun Ilmu Kosmetik Medik; Universitas Indonesia Press: Jakarta, Indonesia, 1997; pp. 135-154.

24. Faradiba Faisal, A.; Ruhama, M. Face Cream Formulation from Lemon Juice (Vitis vinifera L.) with Variations in Elmugator Concentration. Maj. Farm. Dan Farmakol. 2013, 17, 17-20.

25. Smaoui, S.; Hlima, H.B.; Chobba, I.B.; Kadri, A. Development and stability studies of sunscreen cream formulations containing three photoprotective filters. Arab. J. Chem. 2017, 10, S1216-S1222. [CrossRef]

26. Genatrika, E.; Nurkhikmah, I.; Hapsari, I. Formulation of black cumin oil (Nigella sativa L.) as Antiacne Cream against Bacteria Propionibacterium acnes. Pharmacy 2016, 13, 192-201.

27. Mollet, H.; Grubenmann, A. Formulatio Technology Emulsions, Suspensions, Solid Forms; Willey-VCH: Weinheim, Germany, 2001.

28. Ueda, C.T.; Shah, V.P.; Derdzinski, K.; Ewing, G.; Flynn, G.; Maibach, H. Topical and Transdermal Drug Product-Stimuli to the revision process. Pharmacop. Forum 2009, 35, 750-764.

29. Rodina, A.F.; Sobri, I.; Kurniawan, D.W. Antioxidant Cream from Ethanolic Extract of Roselle Calyx (Hibiscus sabdariffa L.). Acta Pharm. Indones. 2016, 4, 15-20.

30. Ainaro, E.P.; Amilia, G.; Sani, E.P. Formulasi Sediaan Masker Gel Pell-off Mengandung Lender Bekicot (Achatina Fulica Bowdich) Sebagai Pelembab Kulit; Fakultas MIPA Unisba: Bandung, Indonesia, 2015; ISSN 2460-6472. Available online: http:/ / karyailmiah.unisba. ac.id/index.php/farmasi/article/view/1625 (accessed on 8 December 2021).

31. Issa, T.S.; Philippe, B.; Raymond, H.; Michel, H.; Jacques, D. Improved kinetic parameter estimation in pH-profile data. J. Int. Pharm. 2000, 198, 39.

32. Wilkinson, J.B.; Moore, R.J. Harry's Cosmeticology; Chemical Publishing Company: New York, NY, USA, $1982 ;$ pp. $298-301$.

33. Provesi, J.G.; Dias, C.O.; Amante, E.R. Changes in carotenoids during processing and storage of pumpkin puree. Food Chem. 2011, 128, 195-202. [CrossRef]

34. Rodriguez-Amaya, D.B.; dan Kimura, M. HarvestPlus Handbook for Carotenoid Analysis; International Food Policy Research Institute (IFPRI) and International Center for Tropical Agriculture (CIAT): Washington, DC, USA, 2004. 